DOI: $10.1515 /$ LPTS-2015-0032

\title{
JUSTIFICATION OF THE UTILITY OF INTRODUCING SMART METERS IN LATVIA
}

\author{
M. Kunickis,A. Dandens, U. Bariss \\ Latvenergo AS \\ 12 Pulkveža Brieža Str., Riga, LV-1230, LATVIA \\ e-mail: maris.kunickis@latvenergo.lv
}

\begin{abstract}
Automatic data reading from smart meters is being developed in many parts of the world, including Latvia. The key drivers for that are developments of smart technologies and economic benefits for consumers. Deployment of smart meters could be launched in a massive scale.
\end{abstract}

Several pilot projects were implemented to verify the feasibility of smart meters for individual consumer groups. Preliminary calculations indicate that installation of smart meters for approximately $23 \%$ of electricity consumers would be economically viable. Currently, the data for the last two years is available for an in-depth mathematical analysis. The continuous analysis of consumption data would be established, when more measurements from smart meters are available.

The extent of introduction of smart meters should be specified during this process in order to gain the maximum benefit for the whole society (consumers, grid companies, state authorities), because there are still many uncertain and variable factors. For example, it is necessary to consider statistical load variations by hour, dependence of electricity consumption on temperature fluctuations, consumer behaviour and demand response to market signals to reduce electricity consumption in the short and long term, consumer's ambitions and capability to install home automation for regulation of electricity consumption.

To develop the demand response, it is necessary to analyse the whole array of additional factors, such as expected cost reduction of smart meters, possible extension of their functionality, further development of information exchange systems, as well as standard requirements and different political and regulatory decisions regarding the reduction of electricity consumption and energy efficiency.

Keywords: smart grids, smart meter, energy efficiency, data transfer.

\section{INTRODUCTION}

The driving forces behind the development of smart grid technologies globally and in the European Union are the increase in electricity consumption, liberalization of the electricity market, the need to invest in the construction of power grids and power plants to ensure a high level of electricity supply security and increase in the 
use of renewable energy sources, seeking the solution to problems of accumulating their energy output on the one hand and implementation of environmentally friendly measures on the other. These smart technologies ensure operational governance over the entire technical and commercial chain of electricity flow, which includes the generation, transmission, distribution, trade, and consumption management stages.

In 2006, the European Commission published its vision for smart grids [1]. The need to limit consumption in peak hours, green initiatives, development of renewable energy sources and energy efficiency are Europe's main motivators behind the creation of the smart grids vision - an expectation that a well-informed consumer will use less energy [2].

One element of smart grids is the smart electricity meter, which introduces new options in grid management - obtaining up-to-date information and governing low-voltage consumption for each electricity end-user. The smart electricity meter combines both electricity consumption metering and grid management and control functions.

The introduction of smart meters is mandated by European Union Directive 2009/72/EC [3]. The economic justification of this process stems from the increase in electricity prices in the long term, broadening of consumer rights, and the level of technological development.

The aforementioned EU Directive 2009/72/EC also requires that each Member State performs an economic assessment of the introduction of smart meters to determine the cost of introducing intelligent metering systems and identify the benefits to be gained by distribution system operators and the public in general.

The technical benefits cannot always be measured against the economic results of the assessment; therefore, it is necessary to assess the utility of investing in smart meters as one element of a smart grid.

Introduction of smart meters creates a mechanism for interaction between the producer and the consumer of electricity. This interactivity applies to the flows of energy, information, and money.

\section{DEVELOPMENT OF POWER GRID AUTOMATION}

Latvia has significant experience in grid automation matters. The creation of anti-damage automation for the high-voltage network began in the 1960s [4], and currently it is equipped with state-of-the-art protection systems. Technological development has brought relay protection and dispatch control systems to the distribution network as well, the medium-voltage network in particular. The low-voltage network, in turn, does not currently have remote monitoring and control capabilities. Therefore, the next stage of the modernisation of power grid control is the introduction of smart technologies to each electricity consumer connection. This goal forms a significant part of the introduction of smart grids and the materialisation of the vision about the removal of informational and communicative barriers between generation, transmission, and distribution of electricity in order to create a fully integrated system that would diagnose the energy system and resolve problems when they arise and ensure a real-time information exchange between the participants in the energy 
system [5]. The basis of the successful introduction and functioning of smart grids is the symbiosis of state-of-the-art communication technologies, information systems, sensors, control meters, and executive mechanisms.

\section{THE BENEFITS OF TECHNOLOGICAL DEVELOPMENT}

According to the data of Sadales tîkls AS, 1.125 million electricity meters have been installed for electricity users in Latvia. These meters are of three types induction, simple functionality electronic, and smart meters. Approximately $70 \%$ of all electricity meters are induction-type meters. Smart meters have already been installed for more than 11,000 corporate customers. The first smart meters in Latvia were installed for the largest industrial users in the mid-1990s, while the first 500 households received theirs in the spring of 2013 [6].

According to the data of Sadales tikkls AS, meters will have to be replaced over the next 10 years due to expiry of their verification terms. On average, between 80 and 120 thousand meters are replaced annually (Fig. 1). Most of the meters to be replaced are of the induction type, the re-verification and further use of which are not useful.

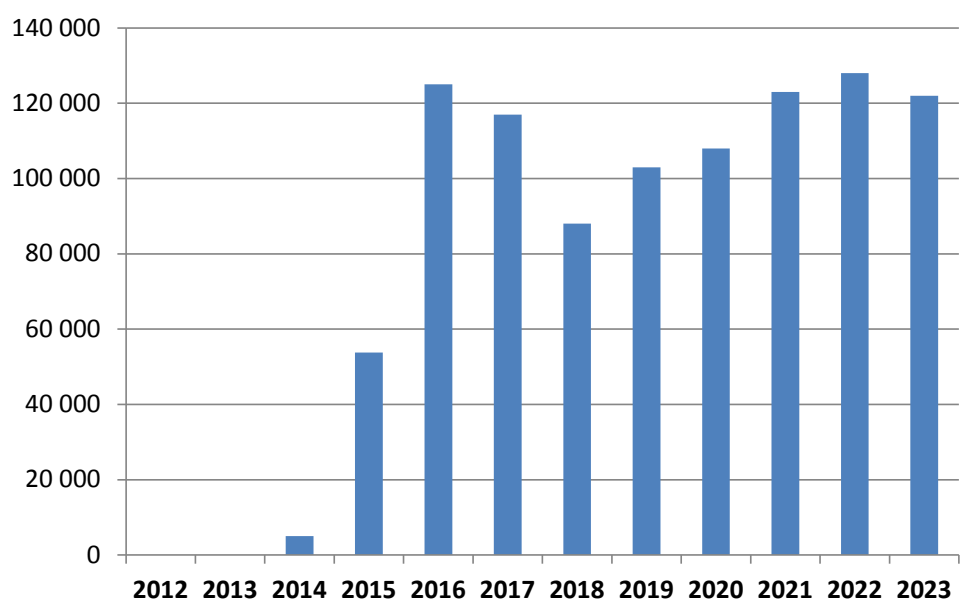

Fig. 1. Number of meters to be replaced each year.

Induction-type meters are obsolete and, despite the well-developed technology and low cost, the further use of these meters is not useful with a view to the development of the electricity market, broader use of renewables, and meeting the energy efficiency requirements. The dynamic changes over the recent years call for the introduction of electricity metering with new functionalities. Smart electricity meters are more sensitive than the conventional meters and record consumption even by devices with very low voltage (such as mobile phone chargers). Taking into account the aforementioned, it would be useful to replace the meter stock using the most modern solutions that will provide not only for the current needs but for those of the future as well. Electronic meters are easier and cheaper to manufacture than those of the induction type, because generally, in view of the economies of scale, 
electronic components are cheaper than moving mechanisms. Electronic meters cost multiple times less than ten years ago.

\section{EVALUATION OF PILOT PROJECTS}

The fitting of households with smart meters on a pilot project scale was commenced in April 2013. Following the installation of smart meters, a study was started on how meters of this type and the information they provide on the current electricity consumption affect the electricity use habits of consumers and motivate them to reduce their consumption. As part of this project, 500 households, segmented in 5 groups by average annual electricity consumption, were fitted with remotely readable smart electricity meters and provided with the option of viewing up-to-date information about electricity consumption on the customer portal of Latvenergo AS. In the study, part of the households (the target group) were regularly reminded about the possibility to "save electricity", while the control group received no special communication. The characteristic consumers of each group were analysed, comparing equal periods - the months of 2013 and 2014. Both groups had a reduction in electricity consumption in this period. This was mainly caused by the customers' interest in the amount they had spent, as well as the weather conditions (warm winter) and, partially, also the revolutionary move to economic lighting due to expanding offers from the LED and CFL technologies, as well as the entry of other state-of-the-art technologies into everyday life. According to the initial evaluation, the first target group displayed a further reduction in electricity consumption. The total reduction in the comparable period (six months during project time vs. pre-project) was $20.4 \%$ [7].

The project yielded valuable experience about the interest of consumers in reducing electricity consumption, the offers of smart meter manufacturers (technological solutions and prices), solutions for information transmission, etc. Up-to-date information about the electricity consumption provides households with much more opportunities to evaluate their electricity use habits and, as a result, be more energy efficient in the use of electricity than before this project.

\section{ECONOMIC JUSTIFICATION}

According to the report published by the European Commission about the results of the cost-benefit analysis on the introduction of smart meters in 27 EU countries [8], Latvia's cost-benefit assessment indicates that the introduction of smart meters is economically justified only for separate consumer groups.

According to publicly available information, the state-conducted assessment indicates that it is cost-effective to install smart meters for households with average yearly electricity consumption in excess of 2,500 kWh.

According to the information compiled by the European Commission, in Latvia's case a major part of the benefit comes from the reduction in electricity consumption itself $(57 \%)$ and the optimisation of personnel costs by the Distribution System Operator (24\%) (Fig. 2). 


\begin{tabular}{|l|l|l|}
\hline \multirow{2}{*}{ LV } & Decrease in energy consumption (57\%) & Cost of smart meters (32\%) \\
\cline { 2 - 3 } & Decrease in personnel costs for the DSO (24\%) & Cost of communication infrastructure (16\%) \\
\cline { 2 - 3 } & $\mathrm{CO}_{2}$ reduction (11\%) & Meter installation cost (8\%) \\
\hline
\end{tabular}

Fig. 2. The benefits of smart meter introduction.

The cost assessment assumes a reduction in consumption by $5 \%$ for households and $2 \%$ for corporate customers. A majority of costs, in turn, consist of the price of the smart meters and the cost of introducing and integrating information systems.

In Latvia, a cost-benefit analysis was performed for the introduction of smart meters to multiple possible large-scale introduction scenarios. These scenarios differ mainly in the meter installation quantity criteria, customer consumption criteria, and the data communication technologies.

It has currently been decided that smart meters will be provided to all customers who consume more than 2,500 kWh of electricity annually. The meters will also be gradually provided to consumers who use less.

Households with an annual consumption above $2,500 \mathrm{kWh}$ could reduce their consumption by $5 \%$ [10]. Electricity suppliers, in turn, reduce costs because fewer visits by inspectors are necessary, losses and thefts are less frequent, etc. Reduced electricity consumption and $\mathrm{CO}_{2}$ emissions are the gains expected on the national level. The overall benefit for the public is presented in Fig. 3.

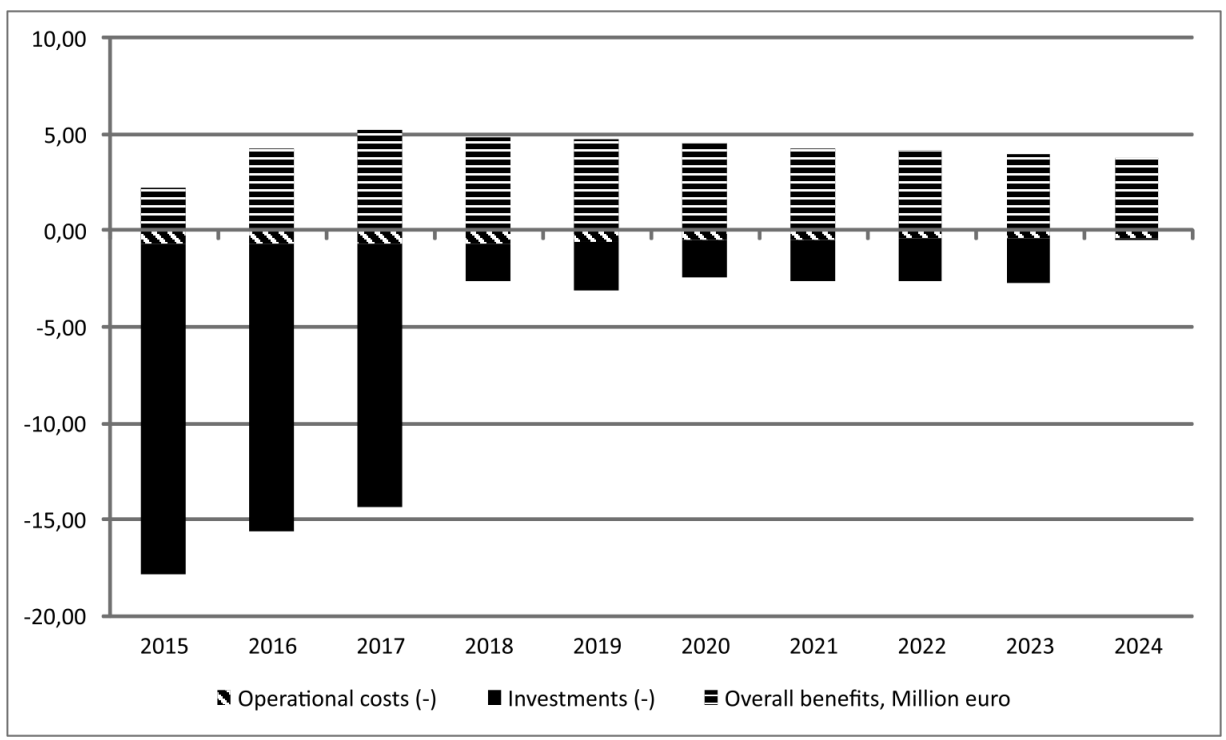

Fig. 3. Benefits of smart meter introduction on the national level.

The cost-benefit calculations of smart meter introduction demonstrate the suitability of smart meters for separate consumer groups. 
Evaluation of the first year results of the household pilot project shows that, following the installation of smart meters, the project group made a larger reduction in their consumption than assumed in the cost-benefit analysis. This is confirmed by the average annual reduction in consumption by the target group of this pilot project, amounting to $19 \%$. This significant decrease was mainly driven by consumers whose consumption exceeds 1,500 kWh / month (Fig. 4).

As evidenced by the results of the analysis of the Latvenergo AS pilot project, the attained electricity savings are, on average, larger than in other similar pilot projects carried out in the European Union. This can be explained by the fact that the customers involved in the project are ones with a relatively high monthly consumption level.

A very important aspect of conducting an economic assessment of the costs and benefits of smart meter introduction is the evaluation of a correct calculation model and the input and output data to be included in it according to their significance and impact. A model is created for the purposes of performing the economic assessment, taking into account the per-unit cost of smart meter installation and, accordingly, the benefit per meter installed. Structure of the model is provided in Fig. 5.

The input parameters of such a calculation model are cost and benefit (dependent variables), and the smart meter introduction scenario is the independent variable.

To ensure flexible modelling, all installation and operation costs and benefits are attributed to a single smart meter unit when selecting various parameters of the dependent variables (the selected communication technology, equipment functionality, consumption levels of the customers who are provided with smart meters, etc.).

Such an approach to the model allows for easy corrections in the meter installation scenarios, adjusting them for various conditions of the dependent variables.

The calculation model must take into account the conclusions of the pilot project about consumption reduction possibilities and optimisation opportunities for the load on the electric grid infrastructure and, consequently, investment, which are not indicated as a benefit by the report of the European Commission [9].

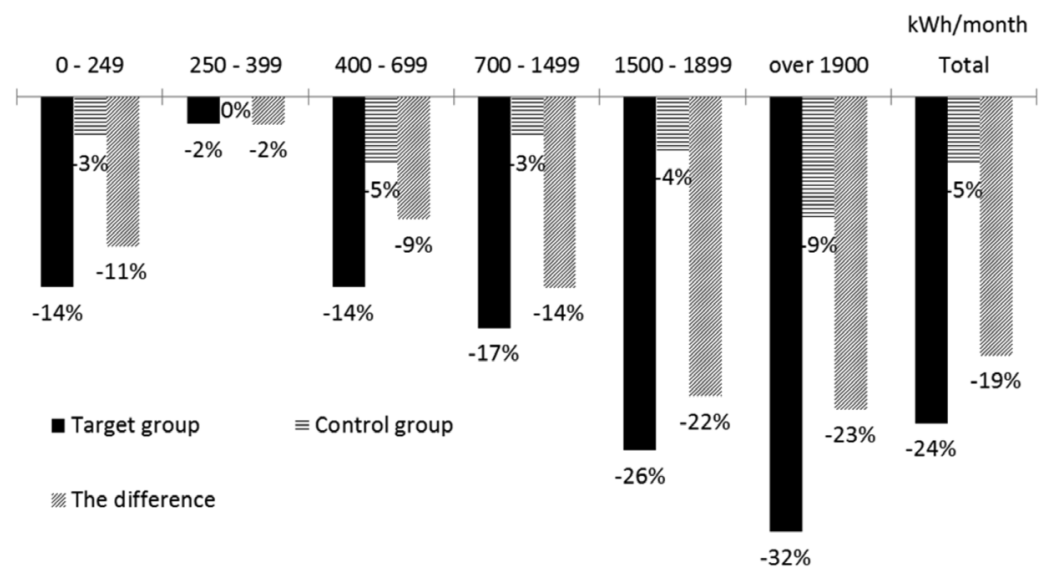

Fig. 4. Reduction in electricity consumption by consumer groups. 


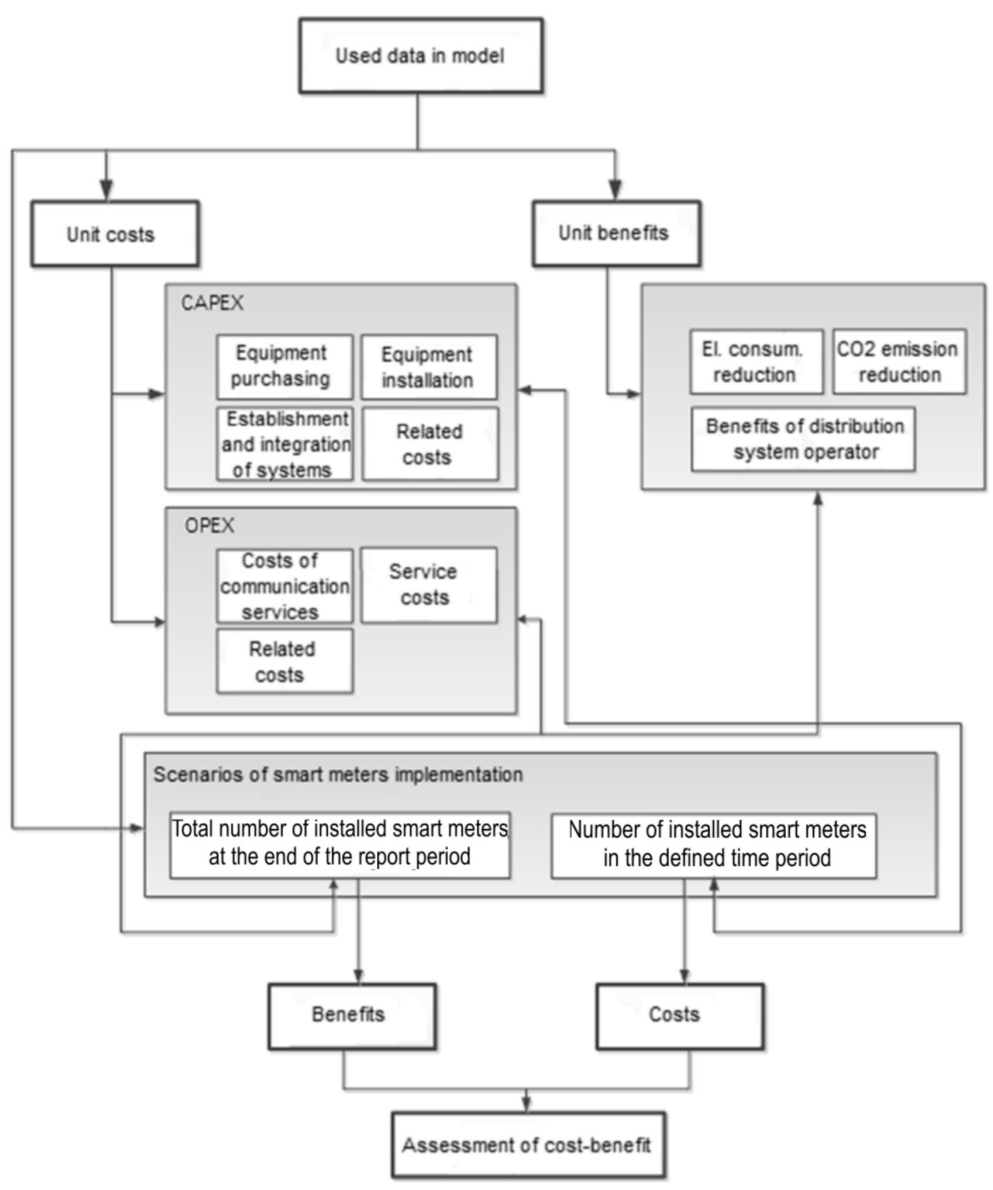

Fig. 5. Smart meter cost-benefit economic assessment model.

\section{FURTHER DEVELOPMENT}

The commenced pilot project shows that it is possible to reduce household electricity consumption through the installation of smart electricity meters and provision of up-to-date and historical information about the use of electricity. However, the data obtained are insufficient for a full static analysis, and further research must be performed over a longer period of time. It is useful to perform analysis by comparing, for example, the change in loads by hour, changes in consumption depending on the outdoor temperature, long-term increase or decrease in electricity consumption, the reaction of customers to motivational factors for consumption reduction, etc. In addition to the factors that characterise the reaction of consumers, changes in installation and operating costs and functionality of smart meters must be analysed.

The metrologic portion of electricity meters has reached maturity - electricity metering is highly precise. Further development of electricity meters can be expected after improvements in PLC data transmission (telemetry using electricity transmission lines and data concentrators in transformer substations) and processing, and a merge with the metering of other utilities is possible. If there is interest 
from customers, it will be possible to equip meters with multiple contactor groups to allow the consumers to freely disconnect any particular electricity-consuming unit at home remotely. However, the introduction of such meters and motivation for the disconnection of devices would require agreements among end-users, distribution networks, traders, electricity price analysts, and other involved parties.

\section{CONCLUSIONS}

Based on the cost-benefit assessment that has already been performed, it is economically justified to introduce smart meters in Latvia to approximately $23 \%$ of the users of electricity until 2017 [10]. Based on the information obtained from the pilot project about the possibility of decreasing electricity consumption by households, a repeated cost-benefit assessment of smart meter introduction should be carried out, reviewing the potential of decreasing electricity consumption after the installation of smart meters, and the benefits provided by smart meters in reducing the duration of disconnection during network faults and the possibility of decreasing network infrastructure costs should be assessed. The decrease in smart meter and system cost must also be taken into account. The economic assessment could use the model described in this paper.

It is expected that, after the large-scale introduction of smart meters, other components of smart meters will be implemented too, including the introduction of low-voltage electric grid management and control solutions, integration of data from smart electricity meters into the grid management systems, development of smart electricity accumulation solutions as an alternative to the construction of new transmission lines and power plants or the operation of power plants in an inefficient mode.

\section{REFERENCES}

1. European Commission. (2006). European SmartGrids Technology Platform. Vision and strategy for Europe's electricity networks of the future. Luxembourg: Office for Official Publications of the European Communities.

2. GEODE Working Group Intelligent Networks. (2009). GEODE position paper on smart metering. Available at http://www.geode-eu.org/uploads/position-papers/_old/ other/011109.pdf.

3. European Parliament and the Council Directive 2009/72/EC concerning common rules for the internal market in electricity and repealing Directive 2003/54/EC [2009] OJ L 211:55, art 2, annex 1 .

4. Barkans J., and Zalostiba D. (2009). Protection against Blackouts and Self-Restoration of Power Systems. Riga: RTU Publishing House.

5. Energy Business Reports. (2011). Smart Grid Industry Market Guide. Available at http:// www.energybusinessreports.com/

6. Bariss, U., Kuzņecova, T., Laicāne, I., and Blumberga, D. (2014). Analysis of factors influencing energy efficiency in a smart metering pilot. Energetika 60(2), 125-135. ISSN 0235-7208.

7. KPFI. Project No. KPFI-14/28 Overview of monitoring results for 2013. 
8. European Commission. (2014). Cost-Benefit Analyses \& State of Play of Smart Metering Deployment in the EU-27. EC Report No. SWD(2014) 189 final, Bruseels. Available at http://www.parlament.gv.at/PAKT/EU/XXV/EU/02/98/EU_29831/imfname_10475991.pdf

9. European Commission. (2014). Benchmarking Smart Metering Deployment in the EU27 with a Focus on Electricity. EC Report No. COM(2014) 356 final, Brussels. Available at http://eur-lex.europa.eu/legal-content/EN/TXT/PDF/?uri=CELEX:52014DC0356\&fr om $=\mathrm{EN}$

10. Avotiņš, A., Kuņickis, M., Bariss, U., and Apse-Apsīitis, P. (2013). Smart metering costbenefit analysis in Latvia. Proceedings of the 14th International Scientific Conference on Electric Power Engineering (EPE 2013). NY: Curran, pp.169-173. ISBN 978-1-62993918-6.

\title{
VIEDO SKAITĪTĀJU IEVIEŠANAS PAMATOJUMS LATVIJĀ
}

\author{
M. Kuṇickis, Ā. Dandens, U. Bariss
}

Kopsavilkums

Automatizēta datu nolasīšana no viedajiem skaitītājiem tiek attīstīta daudzviet pasaulē, ieskaitot Latviju. Galvenie šì procesa virzītājspēki ir viedo tehnologiju attīstība un patērētāju ekonomiskie ieguvumi. Viedo skaitītāju uzstādīšana var tikt uzsākta plašā mērogā.

Tika realizēti vairāki pilotprojekti, lai apstiprinātu viedo skaitīitāju izmantošanas iespējamību privāto patērētāju grupām. Sākotnēji aprēķini parāda, ka ekonomiski pamatota ir viedo skaitītāju uzstādīšana apm. $23 \%$ elektrības patērētāju. Šobrīe izsmel̦ošai matemātiskai analīzei ir pieejami dati par pēdējiem diviem gadiem. Kad tiks iegūti vairāk mērījumi no viedajiem skaitītājiem, varēs izveidot nepārtrauktu patēriņa pastāvīgu analīzi.

Šajā procesā ir jānosaka uzstādāmo viedo skaitītāju apjoms, lai iegūtu maksimālo ieguvumu visai sabiedrībai (patērētājiem, tīklu kompānijām, valsts institūcijām), jo joprojām ir daudz neskaidrību un nepastāvīgo faktoru. Piemēram, ir nepieciešams aplūkot ik stundu slodzes izmaiņu statistiku, elektrības patēriņa atkarību no temperatūras svārstībām, patērētāju rīcību un pieprasījuma reakciju uz tirgus signāliem, lai samazinātu elektrības patēriņu īstermiņā un ilgtermiņā, patērētāju vēlmes un iespējas uzstādīt mājās automatizāciju, lai regulētu elektrības patēriņu.

Lai veidotu atbildi uz pieprasījumu, ir nepieciešams analizēt virkni papildu faktoru, piemēram, sagaidāmo viedo skaitītāju cenu krišanos, to iespējamo funkciju palielinājumu, tālāko informācijas apmaiņas sistēmu attīstību, kā arī standartizētas prasības un dažādus politiskos un regulācijas lēmumus attiecībā par elektrības patēriņu un energoefektivitāti.

29.06.2015. 